\title{
The Social Behavior of Scavenging Birds on Solid Waste Dumps: A Significant Health-Threat to the Inhabitants of Limbe City, Southwest Region, Cameroon
}

\author{
Melle Ekane Maurice ${ }^{1 *}$, Ngenue Abongwa Lucy², Nasako Noto Penda ${ }^{1}$, Mbole Veronique ${ }^{2}$, \\ Bekarikoh Najembe Ekale ${ }^{2}$ \\ ${ }^{1}$ Department of Forestry and Wildlife, Faculty of Agriculture and Veterinary Medicine, University of Buea, \\ Buea, Cameroon
}

*Corresponding Author: Melle Ekane Maurice, Department of Forestry and Wildlife, Faculty of Agriculture and Veterinary Medicine, University of Buea, Buea, Cameroon

\begin{abstract}
Over the past decade, the need for better waste management has become more obvious with the increase in human population growth. Feeding is an essential activity of bird's life which is indispensable for its survival, however, the demands of food acquisition impose significant challenges to both physiology and behavior of birds. This survey was aimed at examining the activity of wild birds on waste dumps in Limbe city. The data collection process started in the month of March and ended in July. The research area was divided into four zones, north, south, east, and western zone. Four solid-dumps were randomly selected from each zone and were visited twice a week for research data collection. On the dumps, observations were done from 6:00am - 6:00pm, and the activities of all the bird species observed were recorded during the period. The results of this study has shown a significant association between bird species, activity, dump-weight, and the waste proximity to human residence, $X 2=24.205 d f=14, P=0.043, X 2=.43 .999 d f=35, p<0.05$, and $r=0.253$, $P=0.000$ respectively. Also, the study showed that the activity profile of Passer griseus (27\%) and Ploceus cucullatus (49\%) were higher as compared to Ploceus luteolus (4\%), Lanius collaries (5\%), Corvus albus 8\%), Bubulcus ibis (5\%), and Pycnonotus barbatus (2\%) respectively. Additionally, the birds' activity recorded a weak association on dump-weight and dump distance to human homes, $X 2=8.343 d f=10, P<0.05$, and X2 = $4.851 d f=8, P<0.05$ respectively. The undulating landscape in Limbe municipality showed a dependency on dump-weight and dump distance from homes, $X 2=128.020 \mathrm{df}=10, P=0.000$, and $r=0.226, P=0.001$ respectively. Also, the dumps with a home-proximity of $1 \mathrm{~m}-20 \mathrm{~m}$ were the most recorded in flat landscape areas, and most of the waste on these dumps were estimated to have a weight range of $1 \mathrm{~kg}-200 \mathrm{kgs}(48 \%), 201 \mathrm{~kg}$ $400 \mathrm{kgs}(27 \%), 401 \mathrm{~kg}-600 \mathrm{kgs}(16 \%)$, and $601 \mathrm{~kg}-800 \mathrm{kgs}(9 \%)$ respectively. Poor waste disposal system has been the main reason behind flood hazards in this sea-shore city, a phenomenon that has witnessed the destruction of both human lives and properties in the past. The city needs a modern waste management system to prevent or reduce the population of birds visiting the dump-sites which would often serve as vectors in cycling pathogens to humans from these dumps.
\end{abstract}

Keywords: Waste management, Wild birds, Waste dumps, Flood hazards, Pathogens

\section{INTRODUCTION}

Municipal and metropolitan solid waste management is one of the most sensitive development issues plaguing developing nations around the world. It can be emphasized that solid-waste generation rates are a function of both population and prosperity (Mane and Hingane, 2012). Majority of developing countries are experiencing exponential growth in population, coupled with other issues associated with urbanization. This increased urbanization associated with growing economies has posed a significant stress on the environment. With the increasing industrialization globally, people are introducing new and complex chemicals into the environment without any rigorous bio-assessment of their toxicity (Mane and Hingane, 2012). Solid waste management has therefore become one of the most crucial issues facing authorities in the fast-growing cities in developing countries (Monney et al., 2013).

The Feeding ecology of birds is an essential aspects of wildlife management, to know the way in which birds exploit their resources and utilize the environment. Thus, the study of feeding ecology is vital to understand the species ecological adaptation to the environment and also a crucial factor to be 
considered while examining the current status of any bird species. House crow prefers urban environment, and is highly adaptive to the urban environment (Ueta, et al., 2003) due to the presence of refuse thrown away by humans in cities which provide easy source of food (Nyari, et al., 2006). Food subsidies appear in the form of human refuse acquired from anthropogenic surfaces such as lawns, roads, parks and other urban landforms (Leu et al. 2008). Such types of food sources make them omnivorous, opportunistic feeders, and important scavengers of the environment.

Over the past decade, the need for better waste management has become more obvious with the increase in population growth, waste complexity (e.g. radioactivity), knowledge of toxicological and ecological effects of anthropogenic chemicals and the analytical capability to detect low concentrations of potentially harmful pollutants. In fact, society is becoming more aware of the vital need for effective waste management to ensure a future viable world civilization. This is evident at the local level, where landfills are becoming overcrowded and difficult to manage; at the national level, with increasing consciousness for resource and waste management; and at the world level, with developing awareness of the global effects of pollution (Jolley and Wang, 1993). Wastes are as old as human society, for most of man's history, people were able to dispose of their biological wastes, bones, skins, fire, ash, tools, shells, pottery materials etc that did not cause harm to their environment (Stefoff, 1991). Simple waste management technologies were effective because the wastes were mostly biodegradable and the populations were small and relatively isolated (Jolley and Wang, 1993). According to Wentz (1995), waste management can be used to describe several processes: the elimination or the reduction of waste, the recycling or reuse of waste (physically destroying, chemically detoxifying or otherwise rendering waste permanently harmless) and finally the disposal of waste depositing material into the land, air, and sea.

Scavenging birds are a conspicuous feature of kampala town, where they live very close to people, who, most of the time, simply accept them as part of life. Their abundance and closeness to man make them an obvious subject of study. Many scavenging birds have adapted to living in harmony with man, even where the environment has been greatly altered through a multiplicity of human activities. Different city council regimes have taken over responsibility of cleaning the city but the size of the population and the impact of increasing incomes on the production of garbage create a good source of food for scavengers. During the 1970s, the largest numbers of scavenging birds in Kampala were at the rubbish tips near the abattoirs in the city. Changing procedures in the 2000s reduced the availability of food at the abattoirs; the biggest concentrations of birds are now at the city rubbish dumps. All these scavengers frequently occur in close proximity to man, especially at feeding sites, with none seemingly directly affected by the presence of the other (Richard Ssemmanda and Derek Pomeroy 2010).

Today, different wildlife species are found outside their natural habitats, such as farmlands, grazing lands, in and around urban areas of several developing countries (Bolwig et al., 2006). Among them, birds are the most known animals and a lot of bird species have been threatened as a result of habitat modifications (Strohbach et al., 2009). Although urban development is considered as a detrimental factor to biodiversity, urban habitats play a great role in conservation of biodiversity (Evans et al., 2009). Daha and Bhuju (2008) stated that waste disposal sites have a great significance for the attraction of different wildlife species. They are used as feeding sites for many wildlife species, such as invertebrates, rodents, jackals, primates, bears and various birds, particularly opportunistic scavengers (Clucas and Marzluff 2011). The food obtained from waste disposal sites has many advantages, it helps to improve survival rate and body condition, enhance reproductive performance, reduces cost of feeding time, minimizes risk of migration, predation and extinctions particularly for endangered species. Thus ecological and biological processes of many species are regulated by those human generated food items (Oro et al., 2013). However, the reduction of food availability in waste disposal sites may also have a negative impact such as shifting in feeding behaviors and other costs (Duhem et al 2003). Birds are well known class of organisms which have an ecological role in both natural and modified ecosystems. They have a great role in ecological functioning and process i.e. bio-indicator of pollution, help to minimize disposable wastes and regulate population of harmful insects and other pests (Sekercioglu, 2006).

The presence of an illegal dumpsite can cause serious health problems for nearby residents as it is an ideal breeding ground for disease vectors such as birds, rats, and mosquitoes (United States Environmental Protection Agency, 1998). Certain respiratory illnesses such as asthma and tuberculosis are also linked to illegally dumped waste (Etengeneng, 2012). The occurrence of illegal dump sites not only affects health and the environment but also the quality of life. According to Madava (2001), illegal 
dumpsites have adverse effects on the basic human rights of people with regards to the standard of living. This is so because the presence of dumpsites does not only deteriorate the quality of the environment but also breaches human rights as it has an impact on community pride. More often than not, the sight and smell that emerges from illegal dumpsites is unpleasant and diminishes land value. Illegal sites that mostly constitute of flammable substances and gases are vulnerable to fires. This not only has an impact on the aesthetic appeal of landscapes but it also diminishes the value of surrounding properties significantly, forcing residents to vacate their homes to further places (United States Environmental Protection Agency, 1998).

\section{MATERials AND MethodS}

\subsection{Description of the Study Area}

Limbe is found in southwest region of Cameroon, with an estimated population of 118,470 inhabitants, it is located between longitude $9^{0} \mathrm{E}$, and latitude $4^{0} \mathrm{~N}$. Climatically, Limbe is dominated by equatorial climate of high rainfall and high temperature. Average monthly temperatures are like any other part of fako division, with the hottest month recording a monthly temperature of $33^{\circ} \mathrm{C}$ (February and March) and the coldest months recording as low as $23^{\circ} \mathrm{C}$ (June-October) (Limbe City Council 2014). Two major seasons exist in the area, the rainy and the dry seasons. In the past, the rainy season occurred from March, extending to October and the dry season from November to February each year. But due to the present climatic change problem, the rainy season extends up to October and December. The primary and secondary forests are rich in flora species in the municipality. However, over $80 \%$ of the primary forest had long been exploited by timber companies. The area is also rich in wildlife species, antelope, monkey, elephant, pangolin, chimpanzee, gorilla, bush baby and squirrel. Moreover, the wild birds include, grey-headed sparrow, swallow, hawk, weaver-bird, sun-bird, owl, bat, kingfisher and parrot (Limbe City Council 2014).

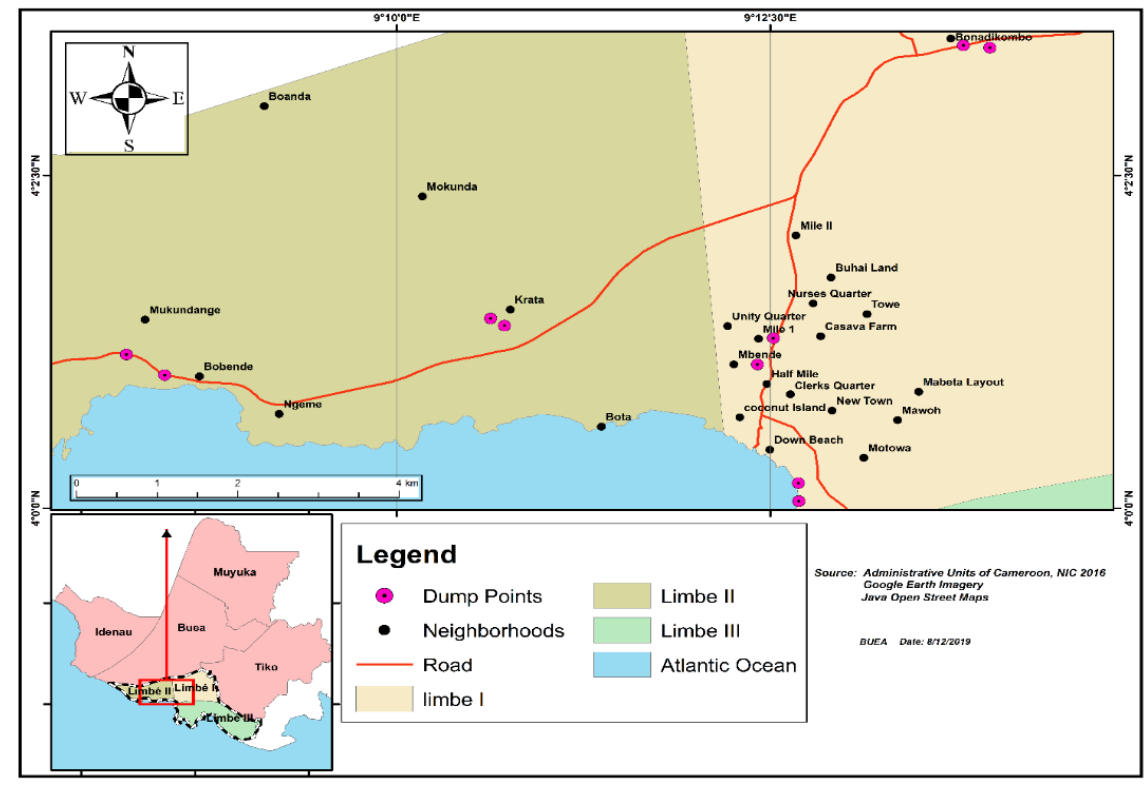

Fig1. Map of Limbe City

\subsection{Methods of Data Collection}

The field research started with a pilot study to test the methods to be used in the process. The exercise witnessed adjustment of some variables in the check-sheet not feasible in the field. Hence, the data collection program started in the month of March and ended in July. The research area was divided into four zones, north, south, east, and western zone. The zonation was based on a sampling method that would reduce bias in the data collection program. Also, four dump-sites were randomly selected from each zone and were visited twice a week for research data collection. On the dumps, observations were done from 6:00am $-6: 00 \mathrm{pm}$, and the activities of all the bird species observed were recorded during the period. More so, the ecological conditions like meteorology, photo-period, weight estimate of dumps, proximity of dump to residential homes, major dump materials, and the land scape were recorded. 
The Social Behavior of Scavenging Birds on Solid Waste Dumps: A Significant Health-Threat to the Inhabitants of Limbe City, Southwest Region, Cameroon

\subsection{Research Data Analysis}

The data was analyzed by using chi-square $\left(\mathrm{X}^{2}\right)$ and correlation (r) statistical models. The inferential and exploratory statistics helped to examine the variables against each other, and to understand their degree of association. The bird species and their activities were examined on dump weight, dump proximity to human residence, and the landscape. Also, there was an examination of dumps on different landscapes, and their proximity to human residence.

\section{RESUlts}

The results of this study showed a significant association between bird species, activity, dump-weight, and the waste proximity to human residence, $X^{2}=24.205 \mathrm{df}=14, \mathrm{P}=0.043$ (fig. 2 ), $\mathrm{X}^{2}=.43 .999 \mathrm{df}=35$, $\mathrm{p}<0.05$ (fig.3), and $\mathrm{r}=0.253, \mathrm{P}=0.000$ respectively (fig.4). Wild birds are ecological contributors, but their presence in human residence generate human-wildlife conflict on farmland, infrastructures, and health problems; over-shadowing their ecological and conservation benefits. Also, human communities have suffered crop-yield loss due to the weaver-bird populations, a conflict that often takes a heavy toll on the economy of the local crop-farmers. The inability of the farmers to afford conventional bird-pestcontrol measures to help reduce their population to harmless levels has been a serious challenge to the agriculture and conservation authorities in Cameroon. The peasant farming tradition in some parts of Cameroon is best known in feeding bird-pests like weaver-birds, francolins, and rodents than humans due to the famers inability to control the pest population. Despite the local methods introduced into fighting the bird-pests population, results are still insignificant. This study observed that the activity profile of Passer griseus (27\%) and Ploceus cucullatus (49\%) were higher as compared to Ploceus luteolus (4\%), Lanius collaries (5\%), Corvus albus 8\%), Bubulcus ibis (5\%), and Pycnonotus barbatus (2\%) respectively (Fig. 5). The disparity in activity frequency might also be an indication of the population concentration of each bird species in the area.

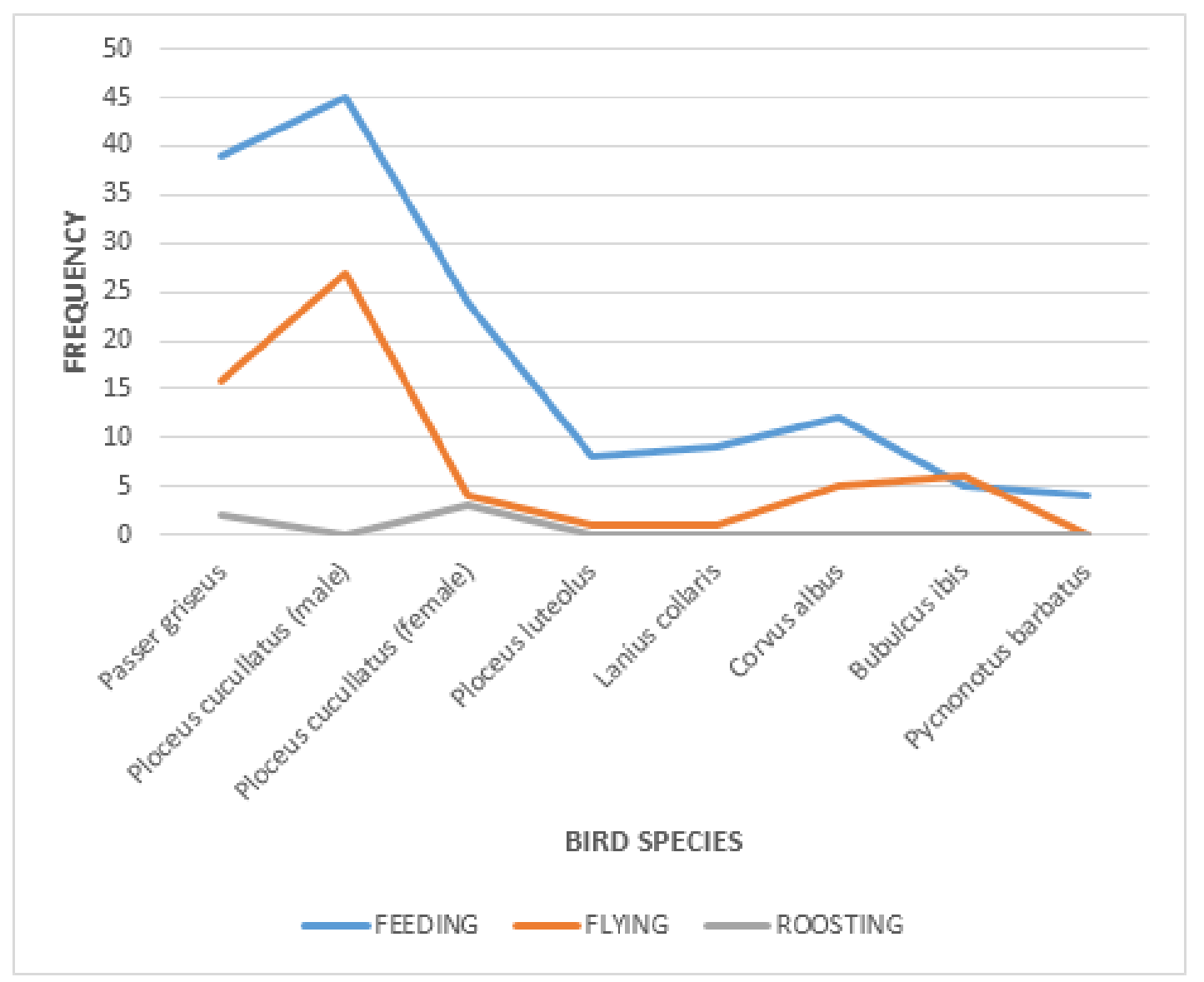

Fig2. Birds species and activity 
The Social Behavior of Scavenging Birds on Solid Waste Dumps: A Significant Health-Threat to the Inhabitants of Limbe City, Southwest Region, Cameroon

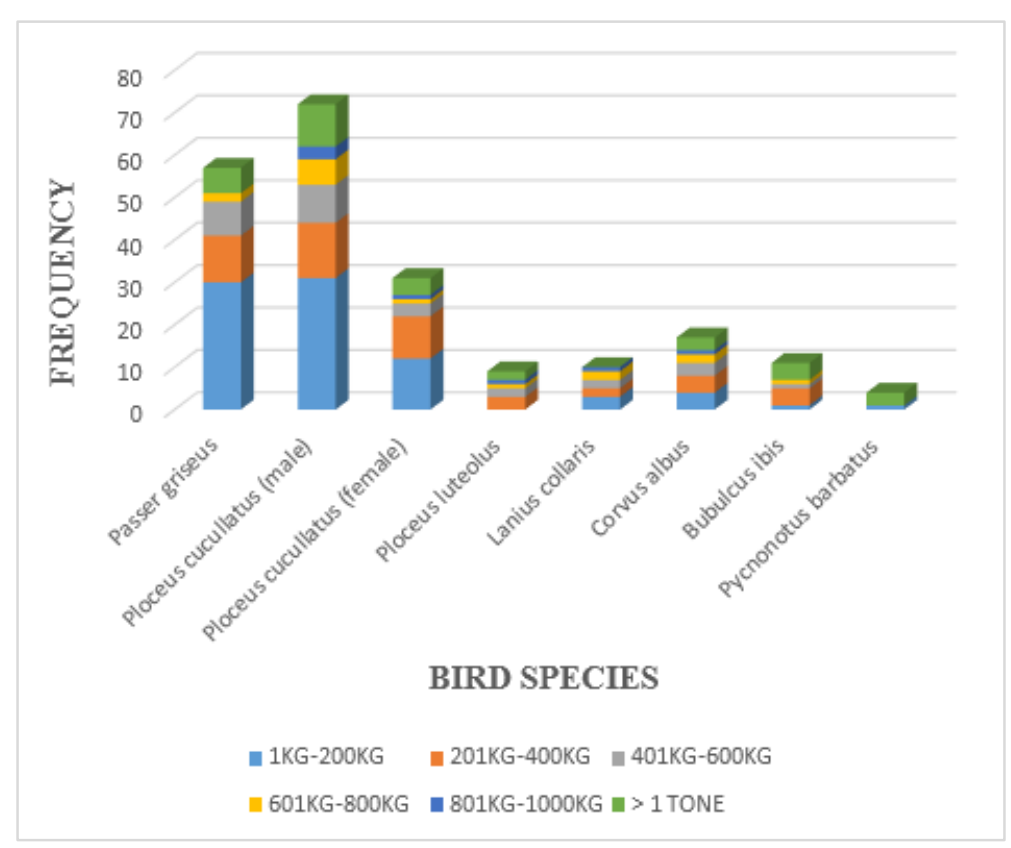

Fig3. Bird species and dump weight estimate

The co-habitation of birds on dump-sites in Limbe city is believed to contribute to poor hygiene and health problems to the residents. The poor waste disposal of the city duelers and its management has raised many questions on whether the unprecedented increase of typhoid and malaria diseases are not the immediate consequences. The population of birds feeding on the dumps was high as observed by this study, with a poor construction plan, characterized by poor drainage facilities, dirty and flooded streets during heavy rains, envisage severe future health problems. People in Cameroon lack proper waste disposal behavior, no sorting of waste is done prior to disposal, creating a huge management challenge to the waste-management company. Hence, the birds scavenging scatter the waste at the dumps littering the streets and nearby residential areas. Moreover, the dumps with $21 \mathrm{~m}-40 \mathrm{~m}$ distance range to residential homes were more frequently visited by the birds, a serious human-health threat. Prevention of epidemic out-breaks in human communities prescribes a proper waste management program in cities, like the transportation of waste to the recycling plants where they are converted into useful products like farm-manure and other materials harmless to human health. Unfortunately, the country's delay to apply advance waste-management technology has exposed the city duelers to offensive odors and infection risk.

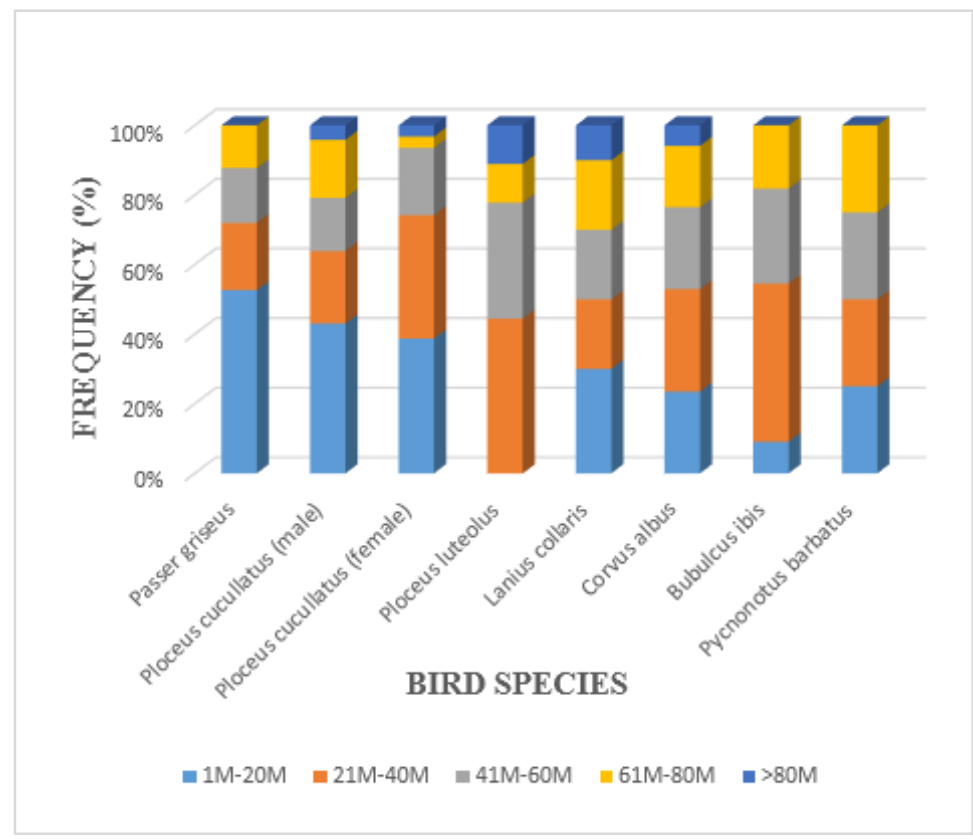

Fig4. Birds species and waste proximity to residence 
The Social Behavior of Scavenging Birds on Solid Waste Dumps: A Significant Health-Threat to the Inhabitants of Limbe City, Southwest Region, Cameroon

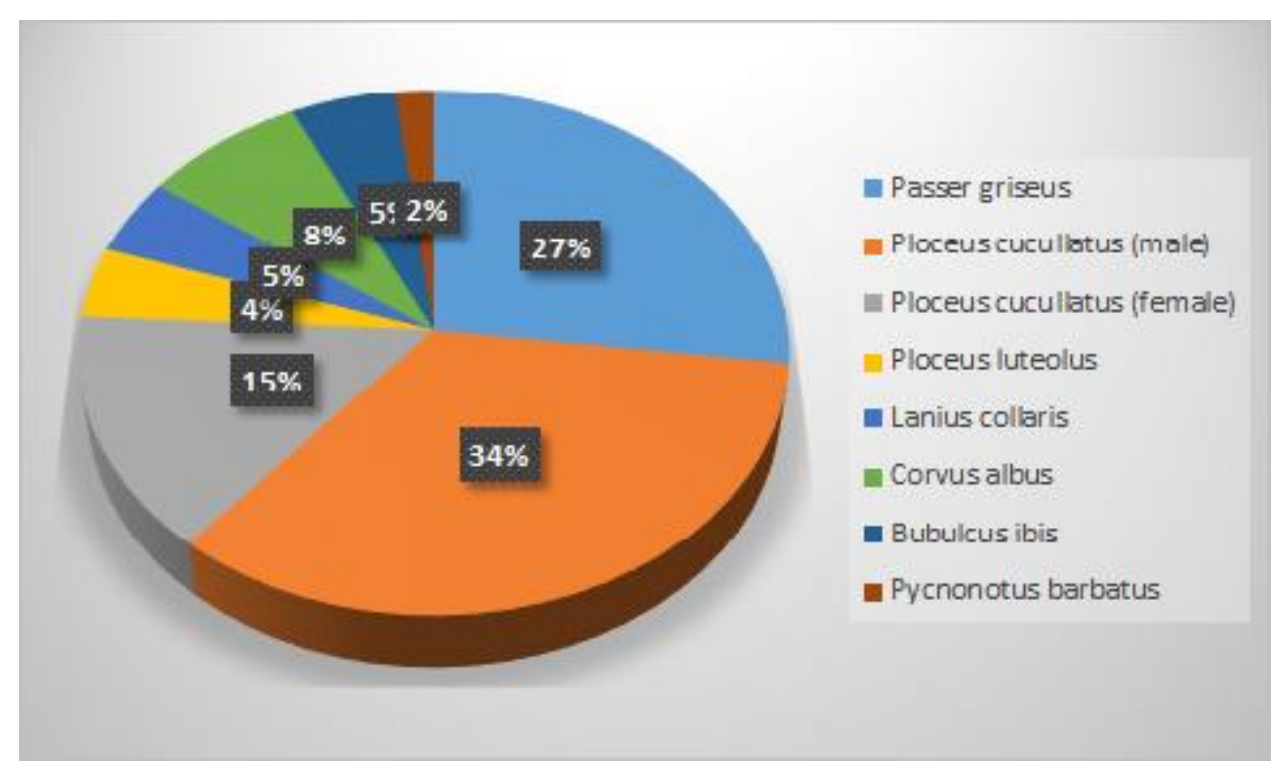

Fig5. Bird species activity frequency

Bird activity recorded a weak association on dump-weight estimate and dump distance to human homes, $\mathrm{X}^{2}=8.343 \mathrm{df}=10, \mathrm{P}<0.05$ (fig. 5), and $\mathrm{X}^{2}=4.851 \mathrm{df}=8, \mathrm{P}<0.05$ (fig.6). Human safety is both the individual and national government responsibility, however, in some developing countries like Cameroon where the administrative power is centralized, there is a tendency for the regional administration to be weak politically due to lack of effective control on human infrastructural management. The situation of Cameroon is not unique on this course, since most neighboring countries are facing the same trend of poor management of regional affaires due to power centralization in the capital, characterized by corruption, self-centeredness, and embezzlement of public funds. Hence, the discontent and frustration of most Cameroonians is reflecting weaknesses on proper management of public infrastructures like waste dumps and the immediate environment. In some cities in Cameroon, especially the English-speaking, local administrative authorities have set aside a week-day for a collective environmental sanitation-activity from 7:00am-12:00am. Unfortunately, the sanitation program is raising controversial questions on its objectives, since the streets are still very much littered with waste, taking weeks and sometimes months to be cleared.

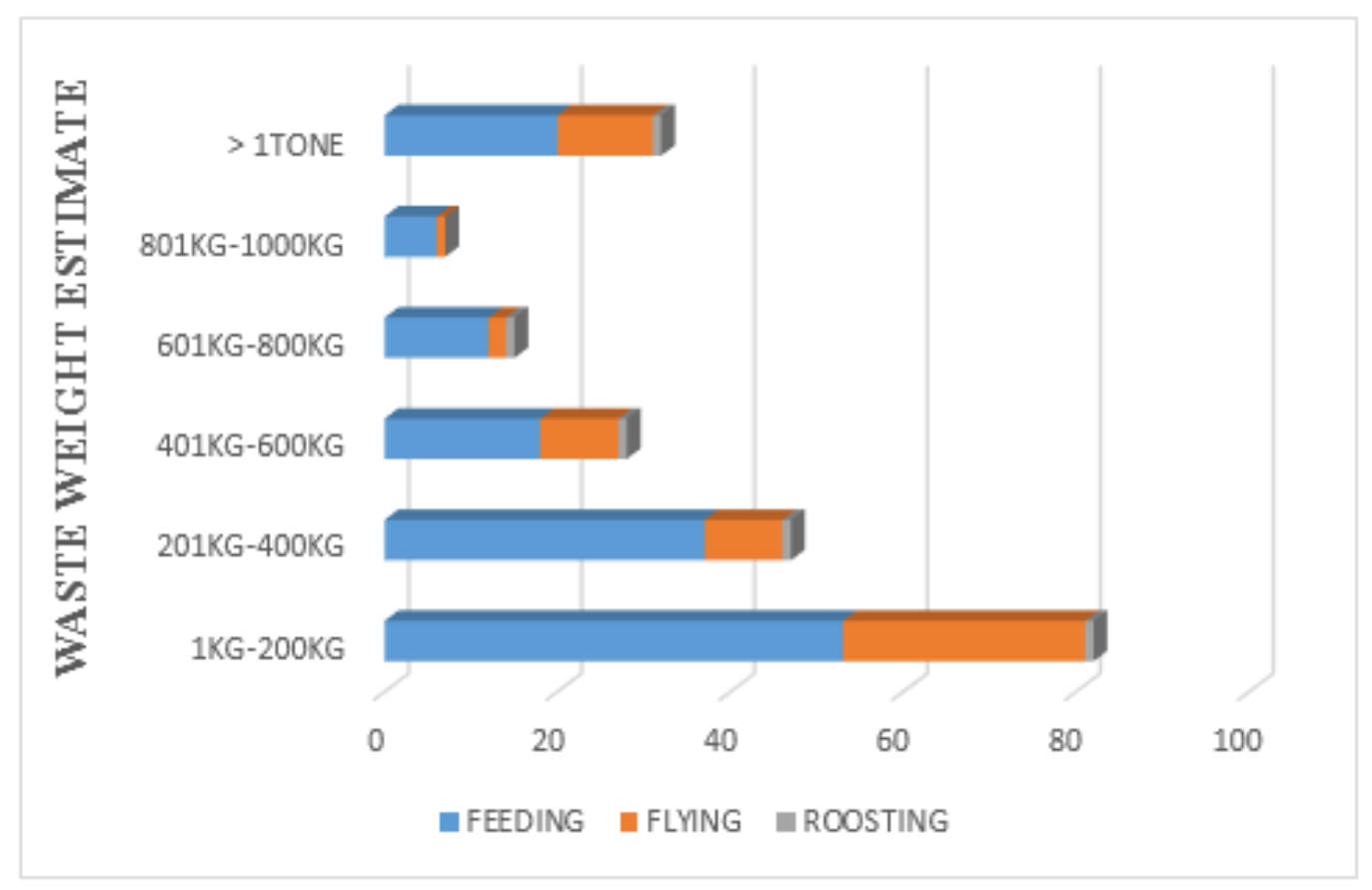

Fig5. Bird activity and dump weight estimate 
The Social Behavior of Scavenging Birds on Solid Waste Dumps: A Significant Health-Threat to the Inhabitants of Limbe City, Southwest Region, Cameroon

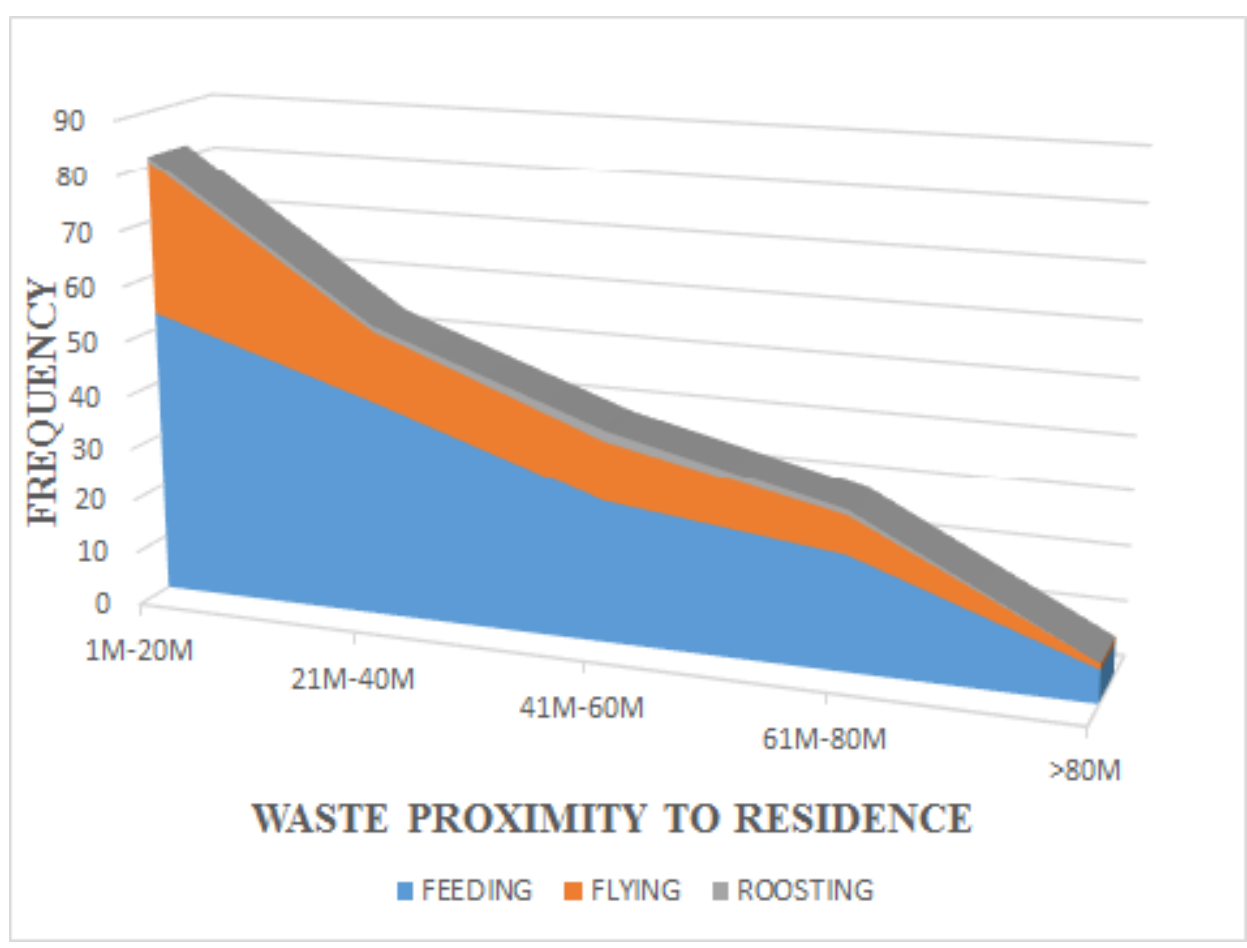

Fig6. Waste proximity and bird activity

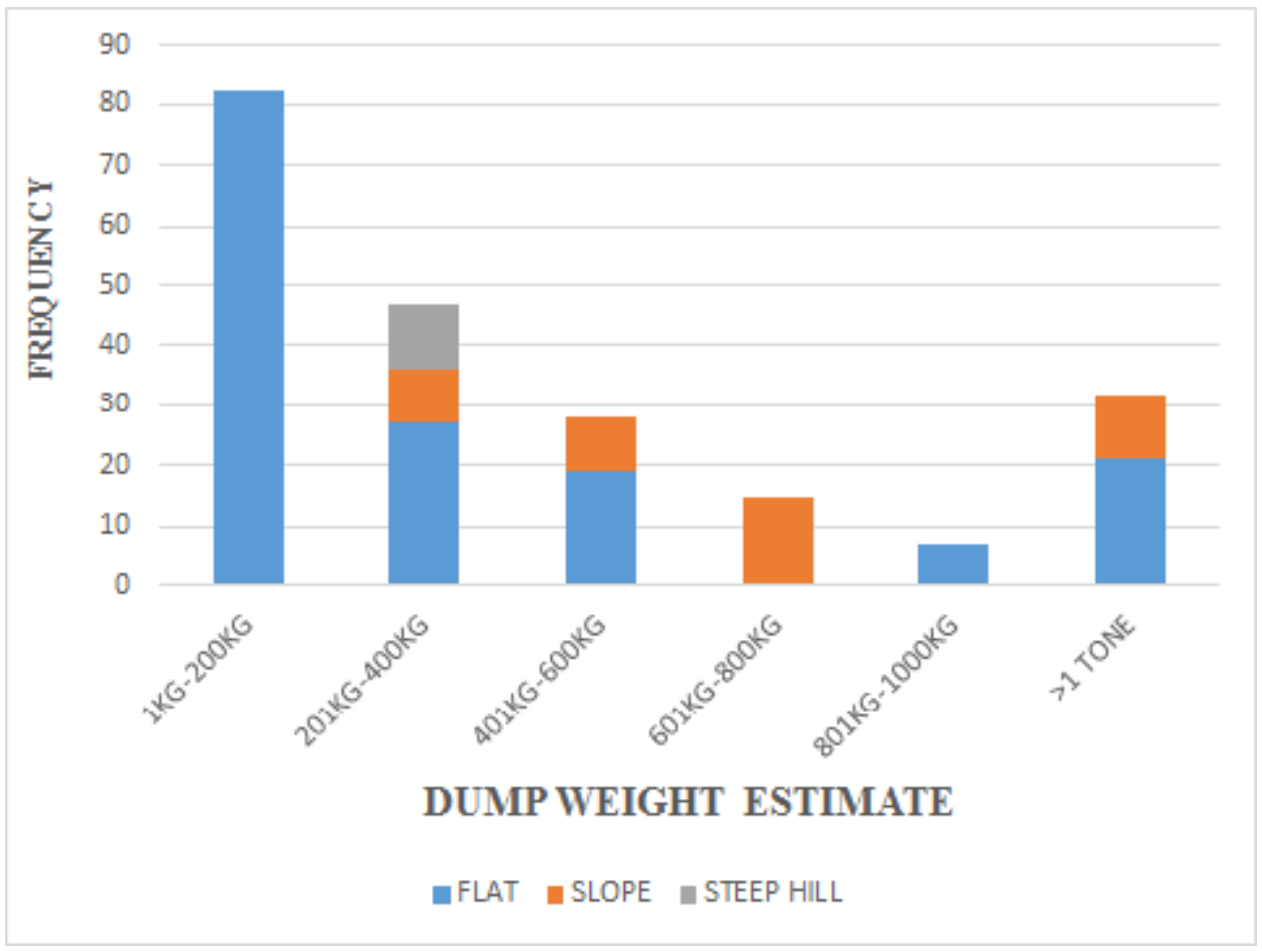

Fig7. Dump weight estimate and landscape

The undulating landscape in Limbe city showed a dependency on dump weight and dump distance from homes, $\mathrm{X}^{2}=128.020 \mathrm{df}=10, \mathrm{P}=0.000$ (fig. 7), and $\mathrm{r}=0.226, \mathrm{P}=0.001$ respectively (fig. 8). The study revealed that most waste dumps are positioned on flat-landscape areas where they can easily be cleared of and transportated to permanent dumping areas situated at the city outskirt. Secondly, the flatlandscape locations prevent waste from being washed into the street drainage where they sometimes cause floods during the wet seasons. Poor waste disposal system has been the main reason behind floods hazards in this sea-shore city, a phenomenon that has witnessed the destruction of both human lives and properties in the past. Also, the dumps with a home-proximity of $1 \mathrm{~m}-20 \mathrm{~m}$ were the most recorded in flat-landscape areas, and most of these dumps were estimated to have weight range of $1 \mathrm{~kg}-200 \mathrm{kgs}$ (48\%), $201 \mathrm{~kg}-400 \mathrm{kgs}(27 \%), 401 \mathrm{~kg}-600 \mathrm{kgs}(16 \%)$, and $601 \mathrm{~kg}-800 \mathrm{kgs}$ (9\%) respectively (fig.9). 
The Social Behavior of Scavenging Birds on Solid Waste Dumps: A Significant Health-Threat to the Inhabitants of Limbe City, Southwest Region, Cameroon

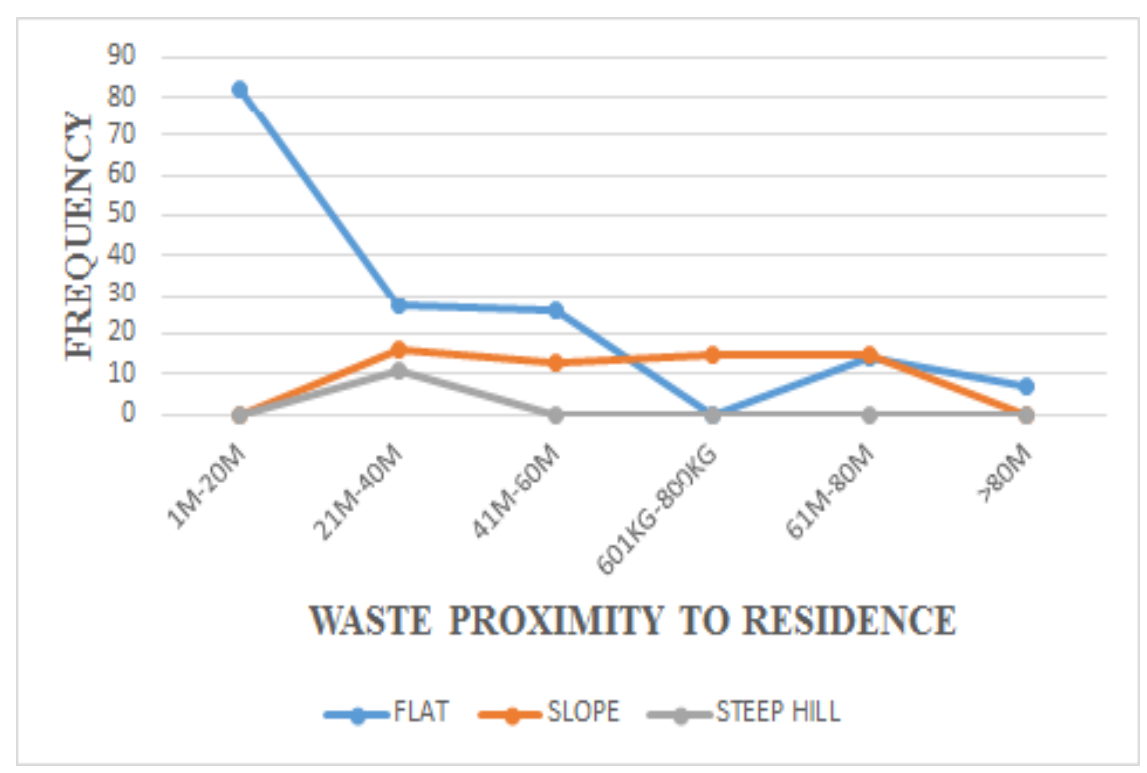

Fig8. Waste proximity to residence and landscape

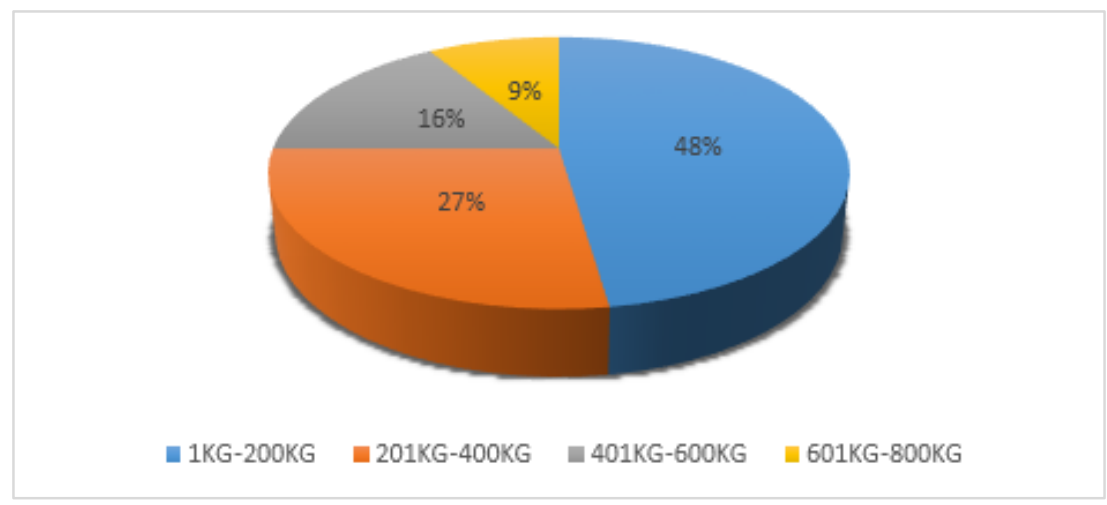

Fig9. Dump-weight estimate frequency

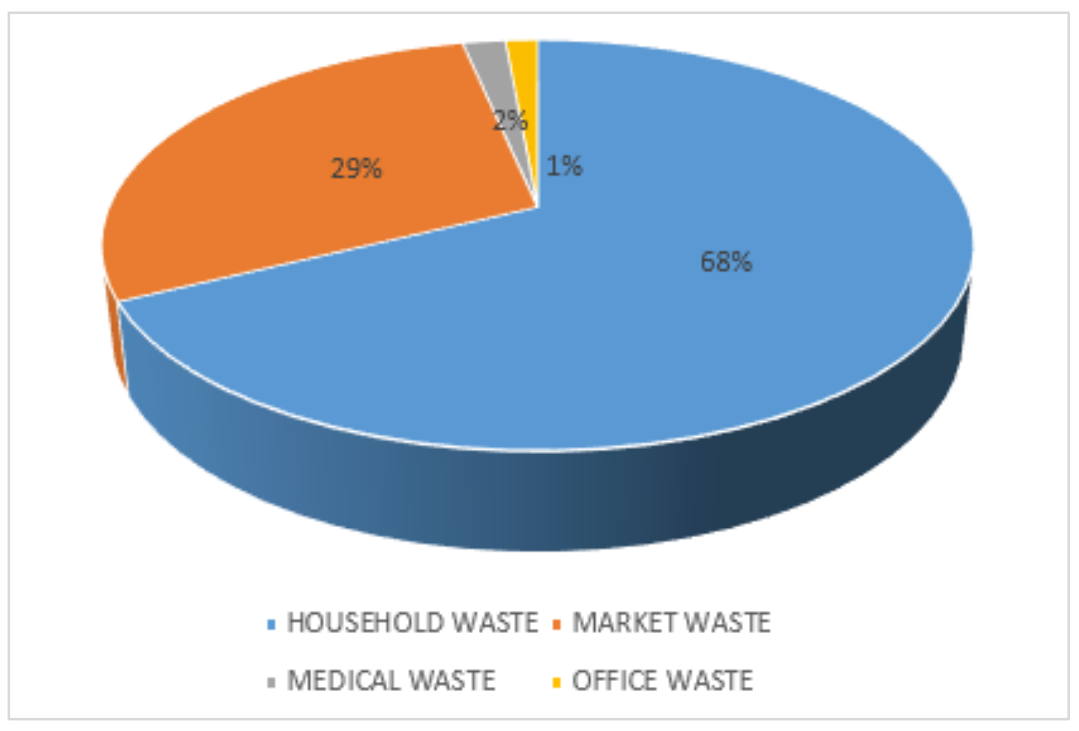

Fig10. Waste type frequency

The major solid waste materials on dump sites were household waste $(68 \%)$, market waste (29\%), medical waste (2\%), and office waste (1\%) (fig.10). However, the feeding activity of birds were observed more on the household and market waste, since they comprised of cooked and uncooked cereal grains, plantains, tubers, and vegetables. The incineration of most medical and office solid waste materials in the city is believed to be the main reason for their reduction in the roadside dumping locations. 


\section{DISCUSSION}

The improper management of waste has the potential to cause serious impacts on the environment and biodiversity. Pollution can accumulate and procedures employed for elimination cause atmospheric and water contamination. However, waste sites may also be of value for biodiversity and migrating bird species. The abundance of organic residues provides species with a predictable spatial and temporal food source that greatly reduces the species both foraging time and home range. Within this frame, rubbish dumps have a high carrying capacity (Donázar 1992, Garrido \& Sarasa 1999). In addition, domestic waste has a high energety content (Sibly \& Mc Cleery 1983). Rubbish dumps in southwestern Europe have been shown to provide key habitats for at least twenty-one bird species (Garrido et al. 2002a) where they feed directly from organic wastes. An additional twenty-two species also use rubbish dumps as a foraging habitat as they indirectly provide food sources such as mice, rats and invertebrates that also concentrate for feeding at these sites.

Birds associated with rubbish dumps could suffer from more than 60 diseases transmissible to humans and domestic animals. In 2006 a mass death of wild birds, including wild pigeons and vultures, was reported in Yemen (BirdLife 2013) during a "Newcastle disease" outbreak of chickens. Wild birds died as a result of the improper dumping of chickens killed by this disease; Newcastle Disease is now endemic in domestic birds (BirdLife 2013). Dead animals dropped off at waste disposal sites may have died from infections that could cause mortality among other birds, including avian influenza, common in the Middle East (Williams and Peterson 2009). Wild birds could potentially transmit diseases along migratory routes, especially because infectious diseases will emerge more frequently in new areas due to climate change (Kirby 2010), as it is the case of the avian influenza or west nile virus (Pradier et al., 2012). Similarly, other species like storks, herons and egrets could reduce the water quality of reservoirs where they roost from carrying pathogenic micro-organisms coming from waste into the systems. However, it should be noted that to date pathogenic pollution has never been cited worldwide, because (Serrano and Cantos 2013) most organic waste is removed from water through appropriate management before being used by people.

Furthermore, feeding on landfills may lead to inhalation or plumage impregnation of a variety of toxic compounds typically found at rubbish dumps (Schmid et al., (2000). These compounds are an issue of public health in the vicinity of rubbish dumps, include several kinds of cancer, embryo malformations, infertility and low neonates weight (Pérez 2000). Some of these toxic substances have damaged birds and inhalation and impregnation could affect their fitness and cause breeding problems to local bird population. Birds feeding on dumps frequently become entangled in plastic, wire, and other debris, or are injured by metal scrap or fire. Similarly, birds can inadvertently ingest plastics, ropes and elastic bands, leading to possible medium term fatalities away from the site, sometimes through the cumulative effect of repeated ingestion. In Spain, deaths of globally threatened white-headed duck (Oxyura leucocephala) have been found due to secondary ingestion, swallowing elastic bands and entangling plastic remains which had come originally from white storks and cattle egrets pellets. These birds, having gathered at a communal roost near the water-bodies, had released some of the plastic they have ingested at a local waste disposal site during roosting and became a risk for the white headed duck population feeding on the lake (Birdlife 2015).

The more food available results in higher survival and productivity rates (Donázar 1992, Garrido \& Sarasa 1999, Serrano \& Cantos 2013). Birds have enough, predictable and ensured food, reducing their movements and improving their individual fitness (Garrido \& Sarasa 1999, Garrido et al. 2002b). Several studies have demonstrated the key role of rubbish dumps in the expansion of the distribution and demography of the cattle egret (Bubulcus ibis) and the white stork (Ciconia ciconia) in the Iberian Peninsula over the past 20 years (Aguirre 2012, Garrido et al. 2012). However, despite the key role of rubbish dumps during the migrating season, it is quite important during the breeding and wintering time. The best examples of the importance of rubbish dumps on the conservation of some birds species in Europe is the increase of populations of black kite (Milvus migrans), red kite (Milvus milvus), griffon vulture (Gyps fulvus), common raven (Corvas corax), carrion crow (Corvus corone), and magpie (Pica pica), (Aguirre 2012; Garrido et al. 2012, Serrano \& Cantos, 2013). Studies revealed that migrating birds which feed from rubbish dumps, act as stop-over sites on the route, increasing survival during a highly stressful and mortality susceptible phase of their lives. In Spain and some north African countries there is a network of dumping sites over the migration routes gathering hundreds or even thousands of individuals feeding and roosting nearby (Garrido et al. 2002a and 2002b, Serrano \& Cantos 
2013). Sometimes, birds have become sedentary or have greatly reduced their migration routes, as it is the case of the white stork in Spain (Garrido \& Sarasa 1999, Aguirre 2012). Rubbish dumps can thus provide new wintering grounds for some species because of the resources they provide (Aguirre 2012, and Global Inter fly way Network 2012).

\section{CONCLUSiON}

Scavenging birds are conspicuously observed on waste dumps in Limbe municipality, where they live very close to people, who, most of the time, simply accept them as part of life. Many scavenging birds, however, have adapted to living in harmony with humans in most cities, even where the environment has been greatly altered through a multiplicity of human activities. Rubbish dumps constitute appropriate feeding sites for many generalist bird species in many parts of Cameroon. Super-abundance of organic residues provides bird species with a predictable spatial and temporal food source that greatly reduces the species both foraging time and home range. The poor waste disposal and treatment has raised many questions on whether the unprecedented increase of typhoid and malaria diseases are not the immediate consequences. The population of birds feeding on the dumps was high as observed by this study, with a poor construction plan, characterized by poor drainage, dirty and flooded streets during heavy rains, envisage severe future health problems to the city duelers. The poor waste disposal system has been the main reason behind flood hazards in this sea-shore city, a phenomenon that has witnessed the destruction of both human lives and properties in the past. The city needs a modern waste management system to prevent or reduce the population of birds visiting the dump-sites which would often serve as vectors in cycling pathogens to humans.

\section{REFERENCES}

[1] Aguirre, J.I. (2012). Cigüeña blanca Ciconia ciconia. En, SEO/BirdLife: Atlas de las aves en invierno en España 2007-2010, pp. 152-153. Ministerio de Agricultura, Alimentación y Medio AmbienteSEO/BirdLife. Madrid.

[2] Bird life International (2015), Waste management: best practices to conserve migrating soaring birds (MSBs) in the rift valley-red sea flyway.

[3] Bird Life International. (2013). Collision and electrocution of birds by powerlines is a conservation concern in Saudi Arabia. Presented as part of the BirdLife State of the world's birds website. Available from: http://www.birdlife.org/datazone/sowb/casestudy/528. Checked: 06/03/2014.

[4] Bolwig S, Pomeroy D, Tushabe H, Mushabe D (2006). Crops, trees, and birds: biodiversity change under agricultural intensifiDtion in Uganda's farmed landscapes. Danish J Geo 106: 115-130.

[5] Clucas B, 0. Drzlu 9MJ (2011). Attitudes and actions toward birds in urban areas: Human cultural di gerences influencebird behavior. Auk 129: 1-9.

[6] Daha R.B, Bhuj R.D (2008). Bird mobility and their habitat at Tribhuvan International Airport, Kathmandu. Nep J Sci Tech 9: 119-130.

[7] Donázar J.A (1992). Muladares y basureros en la biología y conservación de las aves en España. Ardeola 39: 29-40.

[8] Duhem C, Vidal E, Legrand J, Tatoni T (2003). Opportunistic feeding responses of the Yellowlegged Gull Larus michahellis to accessibility of refuse dumps: He gulls adjust their diet composition and diversity according to refuse dump accessibility. Bird Study 50: 61-67.

[9] Etengeneng, D. (2012). Municipal solid waste management in Grahamstown, Republic of South Africa. Novia: Novia University of Applied Sciences. (Degree thesis)

[10] Evans K.L, Newson S.E, Gaston K.J (2009). Habitat influences on urban avian assemblages. Ibis, 151:19-39

[11] Garrido, J. R., \& Sarasa, C. G. (1999). Entre basuras: los vertederos como elementos de gestión y conservación de la avifauna. Garcilla, La, (105), 10-13.

[12] Garrido, J.R., Sarasa, C.G, and Pividal, V. (2002a). El papel de los basureros en el control y gestión de las poblaciones de aves. In, A. Sánchez (Ed): Actas de las XV Jornadas Ornitológicas Españolas, pp.203. SEO/BirdLife, Madrid.

[13] Garrido, J. R., Molina, B. and Delmoral, J. C. (2012). Las Garzas en España, Población Reproductora e Invernante en 2010-2

[14] Garrido, J. R., Sarasa, C.G, and Fernández-Cruz, M. (2002b). Rubbish dumps as key habitats for migration and wintering in the Griffon Vulture (Gyps fulvus) in a migratory bottleneck. I mplications onconservation. In R. Yosef, M.L. Miller \& D. Pepler (Eds) Raptors in the New Milenium. Proceedings of the World Conference on Birds of Prey and Owls, Eilat 2000, pp. 143-151. 
The Social Behavior of Scavenging Birds on Solid Waste Dumps: A Significant Health-Threat to the Inhabitants of Limbe City, Southwest Region, Cameroon

[15] Global Interflyway Network. (2012). Waterbird flyway initiatives: outcomes of the 2011 Global Waterbird Flyways Workshop to promote exchange of good practice and lessons learnt. Seosan City, Republic of Korea, 17-20 October 2011.

[16] Jolley, R.L and Wang, R.G (1993), Effective and Safe Waste ManagementInterfacing Sciences and Engineering with Monitoring and Risk Analysis, United States: Lewis Publishers

[17] Kirby, J. (2010). Review of Current Knowledge of Bird Flyways, Principal Knowledge Gaps and Conservation Priorities. CMS Scientific Council: Flyway Working Group Reviews. Review 2.

[18] Leu, M., S. E. Hanser and S. T. Knick (2008). The human footprint in the west: a largescale analysis of anthropogenic impacts. Ecological Applications, 18: 1119-1139.

[19] Limbe City Council (2014). The Limbe City Council Report 2014

[20] Madava, T. (2001). Illicit dumping of toxic wastes breach of human rights. Review of African Political Economy, 28: 288-290

[21] Mane, T. T,. and Hingane, H. N. (2012). Existing Situation of Solid Waste Management in Pune City, India. Research Journal of Recent Sciences, Vol. 1, pp. 348-351.

[22] Monney, I., Tiimub, B. M., and Henry Chendire Bagah, H. C. (2013). Characteristics and management of household solid waste in urban areas in Ghana: the case of WA. Civil and Environmental Research, Vol.3, No.9, pp. $10-22$.

[23] Nyari, A., C. Ryall and T.A. Peterson (2006). Global invasive potential of the House crow (Corvus splendens) based on ecological niche modeling. Avian Biol., 37(4): 306-311.

[24] Oro D, Genovart M, Tavecchia G, Fowler M.S, Martınez-Abraın A (2013). Ecological and evolutionary implications of food subsidies from humans. Ecol Lett 16: 1501-1514.

[25] Pérez, J. (2000). Vertederos de residuos urbanos. El ecologista 18: 58-61.

[26] Pradier, S., Lecollinet S. and Leblond, A. (2012). West Nile virus epidemiology and factors triggering change in its distribution in Europe. Rev. sci. tech. Off. int. Epiz., 31 (3), 829-844.

[27] Richard Ssemmanda and Derek Pomeroy (2010). Scavenging birds of Kampala: 1973-2009, Scopus 30: $26-31$.

[28] Schmidt, J., Elser, A., Ströbel, R. and Crowe, M. (2000). Dangerous substances in waste. Tech. Rpt. No 38. European Environment Agency. Copebhagen, Denmark.

[29] Sekercioglu CH (2006). Increasing awareness of avian ecological function. Tren ecol evol 21: 8

[30] Serrano, M. and Cantos, F. (2013). Invernada de la gaviota sombría en Madrid. Quercus 331:16-23.

[31] Serrano, M. and Cantos, F. (2013). Invernada de la gaviota sombría en Madrid. Quercus 331:16-23.

[32] Sibley, R. M., and R. H. Mccleery. (1983). Increase in weight of Herring Gulls while feeding. J. Anim. Ecol. 52:35-50.

[33] Stefoff, R (1991). Recycling, United States: Chelsea House Publish

[34] Strohbach M, Haase D, Kabisch N (2009). Birds and the city: Urban biodiversity, land use and socioeconomics. Ecology and Society 14: 31-45.

[35] Ueta, M., R. Kurosawa, S. Hamao, H. Kawachi and H. Higuchi, (2003). Population Change in Jungle Crows. The Mentality of in Tokyo. Global Environ. Res., 7(2): 131-137.

[36] United States Environmental Protection Agency Region (1998). Illegal Dumping Prevention Guidebook, Chicago: Wastes, Pesticides and Toxic Divis Wentz, C.A (1995) Hazardous Waste Management, New York: McGraw Hill

[37] Williams, R.A.J. and Peterson, A.T. (2009). Ecology and geography of avian influenza (HPAI H5N1) transmission in the Middle East and northeastern Africa. International Journal of Health Geographic, 8:47.

Citation: Melle Ekane Maurice, et.al, "The Social Behavior of Scavenging Birds on Solid Waste Dumps: A Significant Health-Threat to the Inhabitants of Limbe City, Southwest Region, Cameroon" International Journal of Research Studies in Biosciences (IJRSB), 8(3), pp 7-17. DOI: http://dx.doi.org/10.20431/23490365.0803002

Copyright: (C) 2020 Authors. This is an open-access article distributed under the terms of the Creative Commons Attribution License, which permits unrestricted use, distribution, and reproduction in any medium, provided the original author and source are credited. 